\title{
Genetic Diversity Analysis of Labeo rohita (Hamilton, 1822) From Hatchery and Dhaura Reservoir of Uttarakhand by Using Microsatellite Markers
}

\author{
Mohd Danish* and I.J. Singh \\ Department of Fisheries Resource Management, College of Fisheries, \\ G.B. Pant University of Agriculture and Technology, Pantnagar-263145, Uttarakhand, India \\ *Corresponding author
}

\section{A B S T R A C T}

Labeo rohita, popularly known as rohu is a widely cultured species in the whole Indian subcontinent. Knowledge of the genetic diversity of this species is important to support management and conservation programs which will subsequently help in sustainable production of this species. DNA markers, mostly microsatellite markers are excellent tool to evaluate genetic variation of populations. The present study deals with genetic diversity analysis of Labeo rohita collected from hatchery and Dhaura reservoir of Uttarakhand through microsatellite marker. Total 20 microsatellite primers were designed by using software Primer-BLAST and Primer-3. A total of 12 microsatellite loci were successfully amplified. After performing native PAGE using amplified 50 DNA samples each, POP GENE Version 1.32 was used to calculate microsatellite variation. The average expected Nei's genetic diversity ranged from 0.328 to 0.529 with mean value of 0.458 for Labeo rohita across all loci from hatchery whereas the average expected gene diversity ranged from 0.328 to 0.529 with mean value of 0.458 for Labeo rohita across all loci from Dhaura reservoir. The observed and expected heterozygosity ranged from 0.2237 to 0.3326 and 0.2786 to 0.3763 respectively for Labeo rohita from hatchery. The mean value of observed heterozygosity was 0.2864 and that of expected heterozygosity was 0.3238 . Mean Fis values were found to be 0.193 at all loci in hatchery and 0.169 at all loci in Dhaura reservoir. The observed and expected heterozygosity ranged from 0.4010 to 0.4612 and 0.4217 to 0.4985 respectively for Labeo rohita from Dhaura reservoir with mean value of observed heterozygosity was 0.4226 and expected heterozygosity was 0.4716 . Mean values for Shannon's information index for all microsatellite loci were 1.1091 for hatchery and 1.1545 for Dhaura reservoir population. Genetic diversity analyses revealed substantial changes in genetic variation and significant genetic differentiation between the wild and hatchery-produced populations of $L$. rohita. These results indicate that genetic drift may have negative effects on the reproductive capacity of the stock, because genetic factors are important in the production of high quality seed. A wide geographical location, different hydro-biological conditions, different habitat and no connectivity between these two water resources and low or absence of gene flow between the populations may be the possible reasons to make reservoir and hatchery populations differentiated.

\section{Introduction}

Molecular markers find application in aquaculture to assess loss of genetic variation in hatcheries through, comparison of variation estimates between hatchery stocks and wild counterparts. The information is useful obtained in monitoring farmed stocks against 
inbreeding loss and to plan genetic up gradation programmes. Molecular markers have proven to be an exceptional indicator of genetic variation within and between populations of many fishery animals (Choi and Kim, 2012; Lee and Hur, 2012). Among the available genetic markers, microsatellites are recognized as an essential tool in population studies (Han et al., 2012; Kim et al., 2013).

All wild-unstocked samples were highly differentiated populations and significantly different from each other and from hatchery samples.Use of DNA markers in population genetic studies of rohu is limited to allozyme (Rana et al., 2004) and mtDNA (Luhariya et al., 2012).

Microsatellite markers have been developed for selected Indian fish species such as rohu (Das et al., 2005; Patel et al., 2009), catla (McConnell et al., 2001), chitala (Punia et al., 2006) and mrigala (Lal et al., 2011). Knowledge of genetic diversity in Indian major carps is considered significant for planning conservation of wild populations (Penman et al., 2005 and Salgueiro et al., 2003) which are facing multiple threats and consequently decline of populations. Wild populations of these carps also face the risk of genetic erosion in their native distribution.

Molecular genetic diversity in fish has been reported to be associated with life history traits that reflect habitat types (DeWoody and Avise, 2000); therefore, it is necessary to investigate genetic variability in the wild and hatchery-produced populations of L. rohita to accumulate significant scientific data fundamental to the success of aquaculture development strategies.

The aim of the present study was to assess genetic variation among hatchery stock and reservoir populations of $L$. rohita using microsatellite DNA markers.

\section{Materials and Methods}

\section{Collection of samples and isolation of genomic DNA}

Kidney tissue samples were collected from each individual $(\mathrm{n}=50)$ of $L$. rohita from hatchery and Dhaura reservoir and stored at $86^{\circ} \mathrm{c}$ in deep freezer for further analysis. DNA was isolated from the dissected kidney tissue through DNA isolation kit purchased (BANGLORE GENEI). Total twenty microsatellite primers were designed by using software Primer-BLAST and Primer-3. To amplify the repeat regions, primers were designed using the web based tool Primer3 (http://primer3.sourceforge.net/)(Rozen and Skaletsky, 2000) to amplify a PCR product of approximately $120-150 \mathrm{bp}$, with an optimum Ta of $55^{\circ} \mathrm{C}$ and a minimum GC content of 40$70 \%$. All the microsatellite primers were screened in 50 DNA samples of fishes from captivity and wild stock.

\section{Amplification of microsatellite loci and analysis of microsatellite data}

All the microsatellite primers were screened in each 50 DNA samples of fishes collected from hatchery and Dhaura reservoirs. A total of 12 microsatellite loci were successfully amplified and were produced clear and polymorphic bands from hatchery and reservoir populations of $L$. rohita. PCR amplification of microsatellite loci were performed in a $25 \mu \mathrm{l}$ reaction mixture, which included 1X PCR buffer (10 mM Tris- $\mathrm{HCl}$ $\mathrm{pH} 9.0,50 \mathrm{mM} \mathrm{KCl}), 0.2 \mathrm{mM}$ of each dNTP, $2.0 \mathrm{mM}$ of $\mathrm{MgCl} 2,5 \mathrm{p}$ mol of each primer, 1.5 U Taq DNA polymerase and 25-50 ng of template DNA. Initial denaturation at 94 degree Celsius for 3 minutes followed by 30 cycles of 94 degree Celsius for 30 seconds, locus specific annealing temperatures for 60 seconds and 72 degree Celsius for 90 seconds and a final elongation of 1 cycle at $72{ }^{\circ} \mathrm{C}$ for 8 
min and stored at $4{ }^{\circ} \mathrm{C}$. Amplified products were mixed with $2(\mu 1)$ of gel loading dye and then separated on $6 \%$ denaturing poly acrylamide gel with 1x TBE on PAGE Gel along with standard marker $\Phi$ X 174/ Hinf I marker at constant power supply of 25 volts for 2 hrs. Polymorphic information content (PIC) of individual primer was estimated using the formula: $\mathrm{PIC}=1-1 / \mathrm{n} \sum_{i=1}^{n} P i j$

Where Pij is the frequency of $\mathrm{jth}$ allele. After performing native PAGE using amplified 50 DNA samples each from both the populations, POP GENE Version 3.4 (Raymond and Rousset, 1998) was used to calculate Nei's observed heterozygosity (Ho), expected heterozygosity (He) and Fixation index (Fis). Nei's average expected gene diversity (Hi) was calculated from the banding pattern of every primer. Individual genotypes were scored using the GeneMapper (version 4.0; Applied Biosystems) with a size standard and an internal control for allele calling; each allele was coded according to its size in nucleotide base pairs (bp). A panel that included all of the alleles detected in the 50 individuals was created for each locus. Possible null alleles and genotyping errors caused by stuttering and/or large-allele dropout were tested using MICROCHECKER (1000 randomizations) (Van Oosterhout et al., 2004). Scoring and human error were estimated by duplicate analyses. The polymorphic information content (PIC) calculated by using the CERVUS version 3.03 (Kalinowski et al., 2007).

\section{Results and Discussion}

\section{Primers amplification results of Labeo rohita collected from Dhaura reservoir}

Twelve microsatellite primers were successfully amplified and showed polymorphism (Table 1). Total 65 numbers of alleles scored in Dhaura stock. Number of alleles per locus ranges from 4 to 7 with mean value of 5.41 per locus, a total of 6 SSR loci was scored by the primer PL-01. The product size ranged from 0.11 to $0.29 \mathrm{~Kb}$ and the PIC value and average expected gene diversity of the primer were 0.62 and 0.519 respectively. A total number of 5 SSR loci were scored by the primer PL-02 and three loci were polymorphic (Tables 2 and 5). The product size ranged from $0.13 \mathrm{~Kb}$ to $0.32 \mathrm{~Kb}$ and the PIC value and average expected gene diversity of the primer were 0.54 and 0.523 respectively. 4 SSR loci were scored for the primer PL-03 with product size ranged from $0.23-0.34 \mathrm{~Kb}$ and the PIC value and average expected gene diversity of the primer were 0.57 and 0.536 respectively. The total of 7 SSR loci was scored for the primer PL-08 (Tables 2 and 5). The product size ranged from $0.24 \mathrm{~Kb}$ to $0.48 \mathrm{~Kb}$ and the average expected gene diversity and PIC value of the primer were 0.59 and 0.549 respectively. Total numbers of 5 SSR loci were scored by the primer PL-10 and three loci were found to be polymorphic. The product size ranged from $0.19 \mathrm{~Kb}$ to $0.51 \mathrm{~Kb}$ and the average expected gene diversity and PIC value of the primer were 0.54 and 0.611 respectively (Tables 2 and 5). 7 SSR loci were scored by the primer PL-11 and the product size was $0.20-0.37 \mathrm{~Kb}$. PIC value and the expected genetic diversity was 0.59 and 0.549 respectively. 6 SSR loci with product size ranged $0.23 \mathrm{~Kb}$ to $0.49 \mathrm{~Kb}$ was scored for the primer PL-13. The average expected gene diversity and PIC value were 0.61 and 0.602 respectively. 5 SSR loci were scored by the primer PL-14 and the average expected gene diversity and PIC value of the primer were 0.53 and 0.506 respectively and product size ranged from 0.14 to $0.33 \mathrm{~kb}$ (Tables 2 and 5). 5 SSR loci were scored by the primer PL-15 and the average expected gene diversity and PIC value of the primer were 0.53 and 0.625 respectively and product size ranged from 0.16 to $0.50 \mathrm{~kb}$ (Tables 2 and 5). 6 SSR loci 
were scored by the primer PL-16 and the average expected gene diversity and PIC value of the primer were 0.478 and 0.56 respectively. Product size ranged from 0.19 to $0.41 \mathrm{~kb} .4$ polymorphic SSR loci were scored by the primer PL-17 and the average expected gene diversity and PIC value of the primer were 0.57 and 0.509 respectively and product size ranged from 0.17 to $0.38 \mathrm{~kb}$ (Tables 2 and 5). 6 SSR loci were scored by the primer PL-20 and the average expected gene diversity and PIC value of the primer were 0.55 and 0.517 respectively and product size ranged from 0.16 to $0.41 \mathrm{~kb}$ (Tables 2 and 5)

\section{Primers amplification results of Labeo rohita collected from hatchery stock}

Twelve microsatellite primers were successfully amplified and showed polymorphism (Table 1). Total 52 numbers of alleles scored in hatchery stock, number of alleles per locus ranges from 3 to 5 with mean value of 4.33 per locus. A total of 4 SSR loci were scored by the primer PL-01. The product size ranged from $0.11 \mathrm{~Kb}$ to $0.24 \mathrm{~Kb}$ and the PIC value and average expected gene diversity of the primer were 0.52 and 0.473 respectively. A total number of $3 \mathrm{SSR}$ loci were scored by the primer PL-02 and all the loci were polymorphic (Tables 3 and 4). The product size ranged from $0.13 \mathrm{~Kb}$ to $0.31 \mathrm{~Kb}$ and the PIC value and average expected gene diversity of the primer were 0.48 and 0.528 respectively. The totals of 5 SSR loci were scored for the primer PL-03 with product size ranged from 0.20 to $0.43 \mathrm{~Kb}$. and the PIC value and average expected gene diversity of the primer were 0.56 and 0.474 respectively. The total of 5 SSR loci was scored for the primer PL-08 (Tables 3 and 4). The product size ranged from 0.27 to $0.36 \mathrm{~Kb}$ and the average expected gene diversity and PIC value of the primer were 0.56 and 0.369 respectively. Total numbers of 4 SSR loci were scored by the primer PL-10. The product size ranged from $0.28 \mathrm{~Kb}$ to $0.53 \mathrm{~Kb}$ and the average expected gene diversity and PIC value of the primer were 0.52 and 0.418 respectively (Tables 3 and 4). 5 SSR loci were scored by the primer PL-11which and the product size was $0.30-0.44 \mathrm{~Kb}$ and the expected genetic diversity and PIC value of the primer 0.56 and 0.497 respectively (Table 3 and 4). 4 SSR loci with product size ranged $0.29 \mathrm{~Kb}$ to $0.47 \mathrm{~Kb}$ was scored for the primer PL-13. The average expected gene diversity and PIC value were 0.52 and 0.529 respectively. 5 SSR loci were scored by the primer PL-14 and the average expected gene diversity and PIC value of the primer were 0.54 and 0.452 respectively and product size ranged from 0.16 to $0.24 \mathrm{~kb}$ (Tables 3 and 4). 5 SSR loci were scored by the primer PL-15 and the average expected gene diversity and PIC value of the primer were 0.56 and 0.511 respectively and product size ranged from 0.19 to $0.43 \mathrm{~kb}$ (Tables 3 and 4). 3 SSR loci were scored by the primer PL-16 and the average expected gene diversity and PIC value of the primer were 0.328 and 0.48 respectively. Product size ranged from 0.15 to $0.40 \mathrm{~kb}$. 4 SSR loci were scored by the primer PL-17 and the average expected gene diversity and PIC value of the primer were 0.52 and 0.439 respectively and product size ranged from 0.18 to $0.30 \mathrm{~kb}$ (Tables 3 and 4). 5 SSR loci were scored by the primer PL-20 and the average expected gene diversity and PIC value of the primer were 0.56 and 0.485 respectively and product size ranged from 0.21 to $0.34 \mathrm{~kb}$ (Tables 3 and 4).

\section{Microsatellite variation and gene diversity analysis}

After performing native PAGE using amplified 50 DNA samples as above, POP GENE Version 1.32 was used to calculate Nei's observed heterozygosity, expected heterozygosity, Nei's genetic diversity and Fixation index (Fis). Average expected gene diversity was calculated from the banding pattern of every primer. 
Table.1 Primer-BLAST designed microsatellite primers for L. rohita

\begin{tabular}{|l|l|c|l|}
\hline Locus & Primer Sequence(5'-3') & Annealing Temp & Annealing Time \\
\hline Lr-01 & $\begin{array}{l}\text { F-GAAAGCTGCTCGTCCTTGAA } \\
\text { R-GAAAGCTGCTCGTCCTTGAA }\end{array}$ & $53^{\circ} \mathrm{C}$ & $1 \mathrm{~min} 30 \mathrm{sec}$ \\
\hline Lr-02 & $\begin{array}{l}\text { F-GGGTGTGGGAGAGAAAGAGAG } \\
\text { R-GGAGTCTGACAAATGCAGCAAG }\end{array}$ & $62{ }^{\circ} \mathrm{C}$ & $1 \mathrm{~min} 30 \mathrm{sec}$ \\
\hline Lr-03 & $\begin{array}{l}\text { F-TCTCAGTGGGTGTCATTACCTG } \\
\text { R-CCCATCAAACCATCTCTCTAGC }\end{array}$ & $52^{\circ} \mathrm{C}$ & $1 \mathrm{~min}$ \\
\hline Lr-08 & $\begin{array}{l}\text { F-CTGACACTCTTATCTCGCTGCC } \\
\text { R-GACCTGAGCAAACAAACCTCAT }\end{array}$ & $53{ }^{\circ} \mathrm{C}$ & $1 \mathrm{~min} 30 \mathrm{sec}$ \\
\hline Lr-10 & $\begin{array}{l}\text { F-TCTCTCTTTGTCTTTCCCCTTG } \\
\text { R-CACAAGCCACTGTTTAGCTTCA }\end{array}$ & $64{ }^{\circ} \mathrm{C}$ & $1 \mathrm{~min}$ \\
\hline Lr-11 & $\begin{array}{l}\text { F-CAAATCTGTGAACATGCAAGC } \\
\text { R-CCTAGTCCACTCTAGTCAGCA }\end{array}$ & $57{ }^{\circ} \mathrm{C}$ & $1 \mathrm{~min} 30 \mathrm{sec}$ \\
\hline Lr-13 & $\begin{array}{l}\text { F-AGATAAGACCCTTCTTCCTCGG } \\
\text { R-TTTATTAGGGAGCGTCGAGTG }\end{array}$ & $62{ }^{\circ} \mathrm{C}$ & $1 \mathrm{~min} 30 \mathrm{sec}$ \\
\hline Lr-14 & $\begin{array}{l}\text { F-CTGTTGGTGACTGTAGGGTGAA } \\
\text { R-GAGAACTCGGTTTGAACATGC }\end{array}$ & $58^{\circ} \mathrm{C}$ & $1 \mathrm{~min}$ \\
\hline Lr-15 & $\begin{array}{l}\text { F-ACAGTAATCTTGTGTCTGTCTCTCTC } \\
\text { R-GTCTAAACGTGTCTGAGCTGTG }\end{array}$ & $55^{\circ} \mathrm{C}$ & $1 \mathrm{~min} 30 \mathrm{sec}$ \\
\hline Lr-16 & $\begin{array}{l}\text { F-TGAATGTTCCAGTCACCACAT } \\
\text { R-GTAATGCAGCGGAGAATAAACC }\end{array}$ & $57{ }^{\circ} \mathrm{C}$ & $1 \mathrm{~min}$ \\
\hline Lr-17 & $\begin{array}{l}\text { F-ACAATTCCTGTGTCAACTGTGC } \\
\text { R-TACCGTCTCAGTCTCTTTTCGG }\end{array}$ & $57{ }^{\circ} \mathrm{C}$ & $1 \mathrm{~min} 30 \mathrm{sec}$ \\
\hline Lr-20 & $\begin{array}{l}\text { F-ATAGTCGAAATTGGTCCTCTGC } \\
\text { R-CAATACCATGACTGAAGTGCC }\end{array}$ & $55^{\circ} \mathrm{C}$ & $1 \mathrm{~min} 30 \mathrm{sec}$ \\
\hline
\end{tabular}

Table.2 Screened primer amplification results of Labeo rohita collected from Dhaura

\begin{tabular}{|c|c|c|c|}
\hline Locus & $\begin{array}{l}\text { Amplified } \\
\text { Product (Kb) }\end{array}$ & $\begin{array}{c}\text { Number of } \\
\text { alleles }\end{array}$ & (PIC) \\
\hline PL- 01 & $0.11-0.29$ & 6 & 0.62 \\
\hline PL-02 & $0.13-0.32$ & 5 & 0.54 \\
\hline PL-03 & $0.23-0.34$ & 4 & 0.57 \\
\hline PL-08 & $0.24-0.48$ & 7 & 0.59 \\
\hline PL-10 & $0.19-0.51$ & 5 & 0.54 \\
\hline PL-11 & $0.20-0.37$ & 7 & 0.59 \\
\hline PL-13 & $0.23-0.49$ & 6 & 0.61 \\
\hline PL-14 & $0.14-0.33$ & 5 & 0.53 \\
\hline PL-15 & $0.16-0.50$ & 5 & 0.53 \\
\hline PL-16 & $0.19-0.41$ & 6 & 0.56 \\
\hline PL-17 & $0.17-0.38$ & 4 & 0.57 \\
\hline PL-20 & $0.16-0.41$ & 6 & 0.55 \\
\hline
\end{tabular}


Table.3 Screened primer amplification results of Labeo rohita collected from hatchery

\begin{tabular}{|c|c|c|c|}
\hline Locus & $\begin{array}{c}\text { Amplified Product } \\
(\mathbf{K b})\end{array}$ & $\begin{array}{c}\text { Number } \\
\text { of alleles }\end{array}$ & PIC \\
\hline PL-01 & $0.11-0.24$ & 4 & 0.52 \\
\hline PL-02 & $0.13-0.31$ & 3 & 0.48 \\
\hline PL-03 & $0.20-0.33$ & 5 & 0.56 \\
\hline PL-08 & $0.27-0.36$ & 5 & 0.56 \\
\hline PL-10 & $0.28-0.53$ & 4 & 0.52 \\
\hline PL-11 & $0.30-0.44$ & 5 & 0.56 \\
\hline PL-13 & $0.29-0.47$ & 4 & 0.52 \\
\hline PL-14 & $0.16-0.24$ & 5 & 0.54 \\
\hline PL-15 & $0.19-0.43$ & 5 & 0.56 \\
\hline PL-16 & $0.15-0.40$ & 3 & 0.48 \\
\hline PL-17 & $0.18-0.30$ & 4 & 0.52 \\
\hline PL-20 & $0.21-0.34$ & 5 & 0.56 \\
\hline
\end{tabular}

Table.4 Genetic Diversity of $L$. rohita from hatchery based on microsatellite markers

\begin{tabular}{|c|c|c|c|c|c|}
\hline Locus & $\begin{array}{l}\text { Observed } \\
\text { Heterozygosity } \\
\text { (Ho) }\end{array}$ & $\begin{array}{l}\text { Expected } \\
\text { Heterozygosity } \\
\text { (He) }\end{array}$ & $\begin{array}{l}\text { Nei's } \\
\text { genetic } \\
\text { diversity } \\
\text { (Hi) }\end{array}$ & $\begin{array}{l}\text { Shanon's } \\
\text { Information } \\
\text { Index }\end{array}$ & $\begin{array}{l}\text { Fixation } \\
\text { Index } \\
\text { Fis }\end{array}$ \\
\hline PL-01 & 0.2682 & 0.2885 & 0.473 & 1.1522 & 0.162 \\
\hline PL-02 & 0.2981 & 0.3042 & 0.528 & 1.1121 & 0.208 \\
\hline PL-03 & 0.3326 & 0.3763 & 0.474 & 1.0972 & 0.289 \\
\hline PL-08 & 0.2549 & 0.3119 & 0.369 & 1.1020 & 0.291 \\
\hline PL-10 & 0.2237 & 0.2786 & 0.418 & 1.0124 & 0.259 \\
\hline PL-11 & 0.2646 & 0.3127 & 0.497 & 1.2149 & 0.188 \\
\hline PL-13 & 0.3015 & 0.3269 & 0.529 & 1.0975 & 0.154 \\
\hline PL-14 & 0.2988 & 0.3420 & 0.452 & 1.0556 & 0.179 \\
\hline PL-15 & 0.3004 & 0.3119 & 0.511 & 1.1061 & 0.132 \\
\hline PL-16 & 0.2817 & 0.3438 & 0.328 & 1.2239 & 0.161 \\
\hline PL-17 & 0.3114 & 0.3329 & 0.439 & 1.1241 & 0.141 \\
\hline PL-20 & 0.3018 & 0.3569 & 0.485 & 1.0118 & 0.153 \\
\hline Mean & $\mathbf{0 . 2 8 6 4}$ & $\mathbf{0 . 3 2 3 8}$ & $\mathbf{0 . 4 5 8 5}$ & $\mathbf{1 . 1 0 9 1}$ & $\mathbf{0 . 1 9 3}$ \\
\hline
\end{tabular}


Table.5 Genetic diversity of $L$. rohita from Dhaura based on microsatellite markers

\begin{tabular}{|c|c|c|c|c|c|}
\hline Locus & $\begin{array}{l}\text { Observed } \\
\text { Heterozygosity } \\
\text { (Ho) }\end{array}$ & $\begin{array}{l}\text { Expected } \\
\text { Heterozygosity } \\
\text { (He) }\end{array}$ & $\begin{array}{l}\text { Nei's genetic } \\
\text { Diversity } \\
\text { (Hi) }\end{array}$ & $\begin{array}{l}\text { Shanon's } \\
\text { Information } \\
\text { Index }\end{array}$ & $\begin{array}{l}\text { Fixation } \\
\text { Index } \\
\text { Fis }\end{array}$ \\
\hline-0.147 & 0.4037 & 0.4764 & 0.519 & 1.2134 & 0.152 \\
\hline-0.198 & 0.4176 & 0.4875 & 0.523 & 1.2379 & 0.203 \\
\hline-0.186 & 0.4153 & 0.4548 & 0.536 & 1.1258 & 0.199 \\
\hline-0.191 & 0.4612 & 0.4985 & 0.549 & 1.2037 & 0.201 \\
\hline-0.188 & 0.4535 & 0.4956 & 0.611 & 1.1928 & 0.198 \\
\hline-0.181 & 0.4143 & 0.4652 & 0.549 & 1.1098 & 0.194 \\
\hline-0.114 & 0.4010 & 0.4789 & 0.602 & 1.1042 & 0.125 \\
\hline-0.122 & 0.4017 & 0.4217 & 0.506 & 1.1026 & 0.136 \\
\hline-0.154 & 0.4254 & 0.4547 & 0.514 & 1.1095 & 0.169 \\
\hline-0.132 & 0.4312 & 0.4674 & 0.478 & 1.1128 & 0.149 \\
\hline-0.126 & 0.4032 & 0.4765 & 0.509 & 1.1062 & 0.146 \\
\hline-0.141 & 0.4441 & 0.4828 & 0.517 & 1.1363 & 0.157 \\
\hline $\mathbf{0 . 1 5 7}$ & $\mathbf{0 . 4 2 2 6}$ & $\mathbf{0 . 4 7 1 6}$ & $\mathbf{0 . 5 3 4}$ & $\mathbf{1 . 1 5 4 5}$ & $\mathbf{0 . 1 6 9}$ \\
\hline
\end{tabular}

The average expected Nei's genetic diversity ranged from 0.328 to 0.529 with mean value of 0.458 for Labeo rohita across all loci from hatchery whereas the average expected gene diversity ranged from 0.328 to 0.529 with mean value of 0.458 for Labeo rohita across all loci from Dhaura reservoir. $73.8 \%$ polymorphism was shown by microsatellite marker in Dhaura reservoir population while $67.3 \%$ polymorphism in hatchery stock. The observed and expected heterozygosity ranged from 0.2237 to 0.3326 and 0.2786 to 0.3763 respectively for Labeo rohita from hatchery (Tables 4 and 5). The mean value of observed heterozygosity was 0.2864 and that of expected heterozygosity was 0.3238 . Mean Fis values were found to be 0.193 at all loci in hatchery and 0.169 at all loci in Dhaura.

The observed and expected heterozygosity ranged from 0.4010 to 0.4612 and 0.4217 to 0.4985 respectively for Labeo rohita from Dhaura reservoir with mean value of observed heterozygosity was 0.4226 and expected heterozygosity was 0.4716 . Mean values for Shannon's information index for all microsatellite loci were 1.1091 for hatchery population and 1.1545 for Dhaura reservoir population (Tables 4 and 5).

When the level of diversity in the hatcheryproduced population was compared with that of the wild population, significant differences were noted in the average number of alleles per locus and the average expected heterozygosity (Wilcoxon signed-rank test; $\mathrm{P}$ $<0.05)$. Because the allele number is positively related to the sample size as well as to the mutation rates at the polymorphic loci, the number of alleles observed at all 12 loci in this study is related to the relatively small size of the samples examined (Liu et al., 2009). Similar genetic variability has been reported for some other marine fish species (An et al., 2011a; Wang et al., 2011), suggesting that these polymorphic microsatellite loci were sufficient to reveal the intraspecific diversity among Labeo rohita. In hatchery strains, the probability of the loss of rare alleles is high (Hutchings and Fraser, 2008). The loss of alleles is more important than the change in allele frequencies, because the latter may 
again change due to random drift, whereas a lost allele cannot be recovered, in which genetic factors are of vital importance for the production of high-quality seed. An obvious degeneration of characteristics has been reported in the cultured fish stock, where the cultured fish does not reach full size, although they mature at an earlier age and have reduced resistance against diseases (Fang et $a l ., 2000)$. Thus, the production of progeny should be based on well-organized brood stock management strategies.

Wang et al., (2002) reported that the effects of inbreeding and genetic drift of hatchery operations contributed to the reduction of genetic diversity of natural stocks of salmonid species. Moreover, siltation since ages, withdrawal of water by constructing dam on main flow are reducing the population size and subsequently declining the genetic variability of the species. The presence of null alleles and/or the inability to separate closely sized alleles due to presence of stutter bands in the microsatellites used might lead to reducing measures of heterozygosity. Microsatellite loci generally show considerable evolutionary conservation, suggesting that primers developed for any one species may often be useful across a wide range of taxa.

However, one drawback of heterologous primers is that mutations in the flanking sequences, to which PCR primers are designed to anneal, can result in nonamplifying PCR null alleles (Hoffman and Amos, 2005; Selkoe and Toonen, 2006). Heterozygote deficiency can also reflect various biological processes such as inbreeding, Wahlund effects and selection (Van Oosterhout et al., 2004). The protection of genetic characteristics of the cultured stock should be considered in artificial reproduction. In the wild population, heterozygote deficit can be explained by several factors, such as the presence of unrecognized null alleles, natural selection acting on genetic markers, mating among relatives, the reduction of heterozygosity in a population caused by a subpopulation structure known as the Wahlund's effect, or a combination of these factors. In hatchery populations, heterozygote deficiency is commonly caused by the limited number of founders, inbreeding, or both (Kohlmann et al., 2005; An et al., 2011b). This deficit may also be attributed to improper domestication processes occurring in the hatchery populations. The FST indicates the proportion of genetic variation that could be attributed to the genetic differentiation processes between the co-specifics from two localities (Coelho et al., 1995). Since there is no physical connection between the hatchery and reservoir, naturally no mixing is possible between stocks and hence they are expected to exhibit high genetic differentiation. However, our results indicate a low level of genetic differentiation between populations with FST values ranging from 0.009 to 0.047 . The sample size in the present study was 50 individuals in each population. Therefore, estimates of population differentiation obtained are unlikely to be confounded by small sample sizes. The overall FST for all samples combined was found to be 0.047 . Thus, approximately $4.7 \%$ of genetic variation was found to be caused by genetic differentiation in $L$. rohita, indicating low level of genetic differentiation. This pattern of variation corresponds to that obtained in other Indian freshwater fishes (Chaturvedi et al., 2011; Gopalakrishnan et al., 2009). A wide geographical location, different hydrobiological conditions, different habitat and no connectivity between these two water resources and low or absence of gene flow between the populations may be the possible reasons to make reservoir and hatchery populations differentiated. The significant differentiation between the 2 populations, 
particularly in the number of private alleles is probably related to several factors such as habitat fragmentation, reduction in the effective number of contributing parents, and the effects of artificial selection on hatchery progeny. Hence, genetic drift has probably played an important role in the loss of genetic diversity and in the differentiation between wild and hatchery-produced populations. The genetic integrity of wild population should be protected from the impact of hatchery production through a carefully planned brood stock management strategy. Unknown and known genetic changes and the possible loss of genetic variation in the wild and hatcheryproduced populations should be monitored by using molecular tools such as nuclear DNA markers.

In summary, genetic diversity analyses revealed substantial changes in genetic variation and significant genetic differentiation between the wild and hatchery-produced populations of $L$. rohita. These results indicate that genetic drift may have negative effects on the reproductive capacity of the stock, because genetic factors are important in the production of high quality seed. A wide geographical location, different hydrobiological conditions, different habitat and no connectivity between these two water resources and low or absence of gene flow between the populations may be the possible reasons to make reservoir and hatchery populations differentiated.

\section{References}

An, H.S., Byun, S.G., Kim, Y.C., Lee, J.W., et al. 2011a. Wild and hatchery populations of Korean starry flounder (Platichthys stellatus) compared using microsatellite DNA markers. Int. J. Mol. Sci. 12: 9189-9202.

An, H.S., Kim, E.M., Lee, J.H., Noh, J.K., et al. 2011b. Population genetic structure of wild and hatchery black rockfish Sebastes inermis in Korea, assessed using cross-species microsatellite markers. Genet. Mol. Res., 10: 24922504.

Chaturvedi, A., Mohindra, V., Singh, R.K., Lal, K.K., Punia, P., Bhaskar, R., Mandal, A., Narain, L., Lakra, W.S. 2011. Population genetic structure and phylogeography of cyprinid fish, Labeo dero (Hamilton, 1822) inferred from allozyme and microsatellite DNA marker analysis. Mol. Biol. Rep., 38: 3513-3529.

Choi, C.G. and Kim, J.M. 2012. Detection of Laminariaceae species based on PCR by family-specific ITS primers. Fish. Aquat. Sci. 15: 157-162.

Coelho, M.M., Brito, R.M., Pacheco, T.R., Figueiredo, D., Pires, A.M. 1995. Genetic variation and divergence of Leuciscus pyrenaicus and L. carolitertii (Pisces, Cyprinidae). J. Fish. Biol., 47: 243-258.

Das, P., Barat, A., Meher, P.K., Ray, P.P. and Majumdar, D. 2005. Isolation and characterisation of polymorphic microsatellites in Labeo rohita and their cross species amplification in related species. Mol. Ecol. Notes, 5: 231-233.

DeWoody, J.A. and Avise, J.C. 2000. Microsatellite variation in marine, freshwater and anadromous fishes compared with other animals. J. Fish Biol., 56: 461-473.

Fang, Y.Q., Weng, Y.Z. and Zhou, J. 2000. Study on early gonadal maturation in cultured large yellow croaker, Pseudosciaena crocea. J. Ocaeanogr. Taiwan Strait, 19: 494-496.

Gopalakrishnan, A., Musammilu, K.K., Basheer, V.S., John, L., Padmakumar, K.G., Lal, K.K., Mohindra, V., Punia, P., Dinesh, K., Manjebrayakath, H., Ponniah, A.G., Lakra, W.S. 2009. Low genetic differentiation in the 
populations of the malabar carp Labeo dussumieri as revealed by allozymes, microsatellites and RAPD. Asian Fish. Sci., 22: 359-391.

Han, H.S., Nam, B.H., Kang, J.H., Kim, Y.K., et al. 2012. Genetic variation in wild and cultured populations of the sea squirt Halocynthia roretzi inferred from microsatellite DNA analysis. Fish. Aquat. Sci., 15: 151-155.

Hoffman, J.I. and Amos, W. 2005. Microsatellite genotyping errors: detection approaches, common sources and consequences for paternal exclusion. Mol. Ecol., 14: 599-612.

Hutchings, J.A. and Fraser, D.J. 2008. The nature of fisheries- and farming-induced evolution. Mol. Ecol., 17: 294-313.

Kalinowski, S.T., Taper, M.L. and Marshall, T.C. 2007. Revising how the computer program CERVUS accommodates genotyping error increases success in paternity assignment. Mol. Ecol., 16: 1099-1106.

Kim, W.J., Shin, E.H., Kong, H.J., Nam, B.H., et al. 2013. Development of polymorphic microsatellite markers suitable for genetic linkage mapping of olive flounder Paralichthys olivaceus. Fish. Aquat. Sci., 16: 303-309.

Kohlmann, K., Kersten, P. and Flajshans, M. 2005. Microsatellite-based genetic variability and differentiation of domesticated, wild and feral common carp (Cyprinus carpio L.) populations. Aquaculture, 247: 253-266.

Lal, K.K., Chauhan, T., Mandal, A., Singh, R.K., Khulbe, L., Ponniah, A.G. and Mohindra, V. 2011. Identification of microsatellite DNA markers for population structure analysis in Indian major carp, Cirrhinus mrigala. J. Appl. Ichthyol., 20: 87-91.

Lee, H.J. and Hur, S.B. 2012. Comparison between phylogenetic relationships based on 18S rDNA sequences and growth by salinity of Chlorella-like species (Chlorophyta). Fish. Aquat. Sci., 15: $125-135$.

Liu, F., Xia, J.H., Bai, Z.Y., Fu, J.J., et al. 2009. High genetic diversity and substantial population differentiation in grass carp (Ctenopharyngodon idella) revealed by microsatellite analysis. Aquaculture, 297: 51-56.

Luhariya, R.K., Lal, K.K., Singh, R.K., Mohindra, V., Punia, P., Chauhan, U.K., Gupta, A., Lakra, W.S. 2012. Genetic divergence in wild population of Labeo rohita. Hamilton, 1822. from nine Indian rivers, analyzed through MtDNA cytochrome b region. Mol. Biol. Rep., 4: 3659-3665.

McConnell, S.K.J., Leamon, J., Skibinski, D.O.F. and Mair, G.C. 2001. Microsatellite markers from the Indian major carp species, Catla catla. Mol. Ecol. Notes, 1: 115-116.

Patel, A., Das, P., Swain, S.K., Meher, P.K., Jayasankar, P. and Sarangi, N. 2009. Development of 21 new microsatellite markers in Labeo rohita. rohu. Anim. Genet., 40: 253-254.

Patel, A., Das, P., Swain, S.K., Meher, P.K., Jayasankar, P., Sarangi, N. 2009. Development of 21 new microsatellite markers in Labeo rohita. rohu. Anim. Genet., 40: 253-254.

Penman, D.J., Gupta, M.V., Dey, M.M. 2005. Carp genetic resources for aquaculture in Asia. World Fish Center technical report, vol.65, pp. 152

Punia, P., Gupta, H.S., Singh, R.K., Mohindra, V., Lal, K.K., Chauhan, V.S. and Lakra, W.S. 2006. Polymorphic microsatellite markers isolated from partially enriched genomic library of Chitala chitala. Mol. Ecol. Notes, 6: 1263-1265.

Rana, R.S., Bhat, K.V., Lakhanpal, S., Lakra, W.S. 2004. Comparative genetic diversity in natural and hatchery 
populations of indian major carps. $C$. catla and L. rohita. Asian Aust. J. Anim. Sci., 17: 1197-1203.

Rozen, S. and Skaletsky, H.J. 2000. Primer3 on the WWW for general users and for biologist programmers. Methods Mol. Biol., 132: 365-386.

Salgueiro, P., Carvalho, G., Pereira, M.J.C., Coelho, M.M. 2003. Microsatellite analysis of genetic population structure of the endangered cyprinid Anaecypris hispanica in Portugal: implications for conservation. Biol. Conserv., 109(1): 47-56.

Selkoe, K.A. and Toonen, R.J. 2006. Microsatellites for ecologists: a practical guide to using and evaluating microsatellite markers. Ecol. Lett., 9: 615-629.
Van Oosterhout, C., Hutchinson, W.F., Wills, D.P.M., Shipley, P. 2004. Micro Checker: software for identifying and correcting genotyping errors in microsatellite data. Mol. Ecol. Notes, 4: 535-538.

Wang, S., Har, J.J. and Utter, F. 2002. Salmonid inbreeding: a review. Rev. Fish Biol. Fish, 11: 301-319.

Wang, L., Meng, Z., Liu, X., Zhang, Y., et al. 2011. Genetic diversity and differentiation of the orange-spotted grouper. Epinephelus coioides) between and within cultured stocks and wild populations inferred from microsatellite DNA analysis. Int. J. Mol. Sci. 12: 4378-4394.

\section{How to cite this article:}

Mohd Danish and Singh, I.J. 2017. Genetic Diversity Analysis of Labeo rohita (Hamilton, 1822) From Hatchery and Dhaura Reservoir of Uttarakhand by Using Microsatellite Markers. Int.J.Curr.Microbiol.App.Sci. 6(6): 1432-1442. doi: https://doi.org/10.20546/ijcmas.2017.606.168 